Scientia Agricola

http://dx.doi.org/10.1590/0103-9016-2013-0425

\title{
Tillage, fertilization systems and chemical attributes of a Paleudult
}

\author{
Evelyn Penedo Dorneles ${ }^{1}$, Bruno Brito Lisboa ${ }^{1}$, André Dabdab Abichequer ${ }^{1}$, Carlos Alberto Bissani², Egon José Meurer², Luciano $^{2}$ \\ Kayser Vargas ${ }^{*}$
}

\author{
${ }^{1}$ State Foundation for Research in Agriculture, R. Gonçalves \\ Dias, 570 - 90130-060 - Porto Alegre, RS - Brazil. \\ 2Federal University of Rio Grande do Sul/Faculty of \\ Agronomy - Dept. of Soil Science, Av. Bento Gonçalves \\ 7712 - 91540-000 - Porto Alegre, RS - Brazil. \\ *Corresponding author <luciano@fepagro.rs.gov.br>
}

Edited by: Tairone Paiva Leão

Received December 19, 2013

Accepted October 03, 2014
ABSTRACT: Tillage and fertilization methods may affect soil fertility. With the aim of assessing changes in soil chemical properties over a period of ten years, soil samples of a Paleudult were collected over nine seasons at three layer depths $(0-5,5-10,10-20 \mathrm{~cm})$ and were chemically analyzed. Grain yield and nutrient export in two summer crops, soybean (Glycine max) and corn (Zea mays), in a field experiment set in Eldorado do Sul, in the state of Rio Grande do Sul, Brazil, were determined. Three soil tillage systems were evaluated, conventional (CT), reduced (RT) and no-tillage (NT), combined with mineral (lime and fertilizers) and organic (poultry litter) fertilization. The no-tillage system stood out as compared to the others, especially in the surface layer, in terms of values of organic matter, soil $\mathrm{pH}$, available phosphorus, cation exchange capacity and base saturation. Phosphorus content was higher under organic than mineral fertilization due to the criteria used for the establishment of fertilizer doses. Under organic fertilization, soil pH values were similar to those obtained in limed soil samples because of the cumulative effect of the organic fertilizer. Soybean yield was lower under NT in comparison to the RT and CT systems. Consequently, soybean grain exported a lower content of nutrients than maize grain. Maize yield was not affected by either tillage or fertilization systems.

Keywords: soil fertility, conventional tillage, no-tillage, organic matter, cation exchange capacity

\section{Introduction}

The natural low fertility of soils in the south of Brazil, mainly in Oxisols and Ultisols (Sánchez and Salinas, 1981), is one of the major constraints on crop productivity in that region. However, chemical attributes of these soils can be altered by management practices that interfere in plant development and, as a consequence, in crop productivity.

Areas of natural vegetation in the south of Brazil are typically converted to agriculture by means of conventional tillage $(\mathrm{CT})$, in which crop residues, fertilizers and lime are incorporated and mixed within the plowing layer (Costa et al., 2010). On the other hand, there is less soil disturbance under conservation tillage managements, so that under no-tillage (NT) crop residues are not incorporated within the soil and fertilizers are surface applied. The outcome of this is that there is an accumulation of organic matter and nutrients, leading to a gradient of the chemical attributes from the soil surface (Costa et al., 2010; Ferreira et al., 2013).

Fertilizers may influence the soil chemical attributes depending on the nature of the fertilizers applied. For annual crops, mineral fertilizers are locally applied in the seedling row or surface broadcasted.

Liming and fertilization practices are intended to be performed by rationally using inputs (Fertilization and Liming Committee, 2004). To accomplish this, it is necessary to understand how management practices will affect soil chemical attributes over the years. Thus, the present research aimed to evaluate the alterations, over ten years, in soil chemical attributes and macronutrient export by grains, as affected by tillage and fertilization systems, in a long term field experiment in the south of Brazil.

\section{Materials and Methods}

In this study, the chemical attributes of a soil were evaluated over a period of ten years (2000-2010), and the productivity and nutrient export were evaluated in two successive crop seasons, soybean (Glycine max), in 2007/2008, and maize (Zea mays), in 2008/2009, in a long-term field experiment established in Eldorado do Sul, in the state of Rio Grande do Sul (RGS), Brazil $\left(30^{\circ} 51^{\prime} \mathrm{S}\right.$ and $\left.51^{\circ} 38^{\prime} \mathrm{W}\right)$. The site is located in the region of the Depressão Central, which has a climate considered subtropical humid, with an annual average temperature of $19.4{ }^{\circ} \mathrm{C}$ and average rainfall of $1.490 \mathrm{~mm}$ per year (Bergamaschi and Guadagnin, 1990). The soil is a Paleudult, acidic, with natural low fertility, low organic matter content and sandy clay loam texture.

Before the experiment was installed, the area had been preserved with natural vegetation for more than 15 years. Agricultural field operations were predominantly mechanized, with grain crops being sown directly over natural vegetation when the experiment started (Bizarro et al., 2011).

From the field experiment, three tillage systems were evaluated: conventional tillage $(\mathrm{CT})$, reduced tillage (RT) and no-tillage (NT). Mineral and organic fertilization were also evaluated. Treatments were set up in a split-plot design, with fertilization systems in the main plots $(30 \times 30 \mathrm{~m})$ and tillage systems in sub-plots $(7.5 \times$ $30 \mathrm{~m}$ for CT and RT and $15 \times 30 \mathrm{~m}$ for NT), with three replicates and repeated measurements over time.

All data were submitted to analysis of variance (ANOVA), at a significance level of $5 \%$, using the Mixed procedure from SAS (v. 9.0). Akaike's Information Criterion (AIC) was used to evaluate the covariance matrix 
that best fit the data (Akaike, 1974). The models included the fixed effects of tillage, fertilization, soil layer and sampling time (repeated measurement over time) and their interactions, and the random effect of block. When significant differences were detected, means were compared by the Tukey test $(p<0.05)$.

Mineral and organic fertilizations were performed according to standard soil management practices as recommended by the Fertilization and Liming Committee (1995; 2004) for RGS. In 2000, after the desiccation of the natural vegetation and before soil tillage, lime was broadcasted in the plots where mineral fertilization would be applied. That was the only time that liming was performed, since acidity indicators are still satisfactory. Mineral basal fertilization was applied in seedling rows, while topdressing fertilization was manually broadcasted, according to crop demands.

The organic fertilization plots were topdressed with poultry litter, in doses determined according to the chemical composition of the residue and the demand for nutrients of the crops (Table 1). Thus, organic fertilization rates were based on the demand for $\mathrm{P}$, when soybean was cropped, or N, when maize or winter cereals were cropped. In both cases, the aim was to reach a fertilization rate equivalent in $\mathrm{P}$ or $\mathrm{N}$ to those applied to the plots that received mineral fertilization.

Poultry litter was always manually broadcasted prior to soil tillage operations. Until the winter of 2003, organic fertilization was performed preceding all crops,

Table 1 - Physical and chemical properties of organic fertilizers used in the field experiment.

\begin{tabular}{lcccc}
\hline Properties & Lot $1^{1}$ & Lot $2^{2}$ & Lot $3^{3}$ & Amount applied \\
\hline Moisture $\left(\mathrm{g} \mathrm{kg}^{-1}\right)$ & 225 & 220 & 240 & $\mathrm{~kg} \mathrm{ha}^{-1}$ \\
$\mathrm{C}\left(\mathrm{g} \mathrm{kg}^{-1}\right)$ & 300 & 290 & 350 & - \\
$\mathrm{N}\left(\mathrm{g} \mathrm{kg}^{-1}\right)$ & 18 & 26 & 24 & 12,015 \\
$\mathrm{P}_{2} \mathrm{O}_{5}\left(\mathrm{~g} \mathrm{~kg}^{-1}\right)$ & 25.2 & 45.8 & 36.6 & 815 \\
$\mathrm{~K}_{2} \mathrm{O}\left(\mathrm{g} \mathrm{kg}^{-1}\right)$ & 22.8 & 38.4 & 26.4 & 1,240 \\
$\mathrm{Ca}\left(\mathrm{g} \mathrm{kg}^{-1}\right)$ & 81 & 32 & 17 & 2,028 \\
$\mathrm{Mg}\left(\mathrm{g} \mathrm{kg}^{-1}\right)$ & 5.6 & 10 & 7.9 & 272 \\
$\mathrm{~S}\left(\mathrm{~g} \mathrm{~kg}^{-1}\right)$ & 4 & 4 & 3.4 & 148 \\
$\mathrm{Fe}\left(\mathrm{g} \mathrm{kg}^{-1}\right)$ & 1.1 & 5.3 & 9.5 & 163 \\
$\mathrm{Na}\left(\mathrm{g} \mathrm{kg}^{-1}\right)$ & 7.6 & 6.4 & 3.3 & 238 \\
$\mathrm{Cu}\left(\mathrm{mg} \mathrm{kg}^{-1}\right)$ & 61 & 524 & 281 & 8 \\
$\mathrm{Zn}\left(\mathrm{mg} \mathrm{kg}^{-1}\right)$ & 454 & 508 & 287 & 16 \\
$\mathrm{Mn}\left(\mathrm{mg} \mathrm{kg}^{-1}\right)$ & 448 & 816 & 457 & 20 \\
$\mathrm{~B}\left(\mathrm{mg} \mathrm{kg}^{-1}\right)$ & 17 & 22 & 32 & 1 \\
$\mathrm{Cd}\left(\mathrm{mg} \mathrm{kg}^{-1}\right)$ & $\mathrm{nd}$ & $\mathrm{nd}$ & 0.3 & 0 \\
$\mathrm{Cr}\left(\mathrm{mg} \mathrm{kg}^{-1}\right)$ & $\mathrm{nd}$ & $\mathrm{nd}$ & 11 & 0 \\
$\mathrm{Ni}\left(\mathrm{mg} \mathrm{kg}^{-1}\right)$ & $\mathrm{nd}$ & $\mathrm{nd}$ & 13 & 1 \\
$\mathrm{~Pb}\left(\mathrm{mg} \mathrm{kg}^{-1}\right)$ & $\mathrm{nd}$ & $\mathrm{nd}$ & 4 & 0 \\
$\mathrm{NV}(\%)$ & 10 & 8 & 6 & $3,322^{4}$ \\
$\mathrm{pH}$ & 8.8 & 8.7 & 8.9 & - \\
\hline
\end{tabular}

'Used from summer 2000 to winter 2003; 'used from summer 2003/2004 to summer 2005/2006; ${ }^{3}$ used from summer 2006/2007 until the end of the experiment; ${ }^{4}$ Equivalent to $\mathrm{CaCO}_{3} ;{ }^{5} \mathrm{nd}=$ not determined. with the exception of soybean in the 2002/2003 season. After that, until the summer of 2006/2007, it was performed only preceding the summer cropping and, since then, it was interrupted due to the detection of high levels of $\mathrm{P}, \mathrm{K}$ and other nutrients, as well as the correction of soil acidity, caused by the cumulative effect of the application of the residue.

Conventional tillage was performed with one plowing, to a depth of $20 \mathrm{~cm}$, followed by one or two disking operations, depending on surface conditions. Reduced tillage consisted of one pass with a chisel plough (20 $\mathrm{cm}$ deep). Under no-tillage, a seed drill with capability for seed and fertilizer application in variable row spacing was used for direct seeding. Up to the third year, CT and RT were applied before both winter and summer crops. Thereafter, these tillage systems were adopted only for summer crops, as the winter crops received NT in all plots.

Soybean was the first crop established in the experimental area, in 2000/2001 season. Thenceforward, the field underwent an annual rotation between soybean and maize in the summer crop season. During the winter crop season, the field was cropped alternately with a consortium of black oat (Avena strigosa) and vetch (Vicia sativa), as cover crops, and wheat (Triticum aestivum) or oat (A. sativa) as grain crops.

During the course of the experiment, soil samples were taken from each plot, with a sampling auger, at depths of $0-5,5-10$ and $10-20 \mathrm{~cm}$. Soil sampling was performed in 09/2000, before the experiment set up; in $10 / 2001$, before maize sowing; in 06/2002, after maize harvest; in 11/2004, before maize sowing; in 10/2005, before soybean sowing; in 12/2006, before maize sowing; in 05/2008, after soybean harvest; and 07/2010, during the winter crop season. After sampling, soil samples were homogenized and dried at $40{ }^{\circ} \mathrm{C}$ and then ground in a mill and screened through a $2.0 \mathrm{~mm}$ sieve. The soil samples were analyzed for organic matter, $\mathrm{pH}\left(\mathrm{H}_{2} \mathrm{O}\right)$, SMP index, extractable $\mathrm{P}$ (Mehlich-1), exchangeable $\mathrm{K}, \mathrm{Ca}, \mathrm{Mg}$ and $\mathrm{Al}$, potential acidity $(\mathrm{H}+\mathrm{Al})$, cation exchange capacity (CEC) at pH 7.0 and base saturation using standard methods (Sparks et al., 1996).

The crop productivity and nutrient export by grains were measured during the 2007/2008 soybean season and the 2008/2009 maize season. In order to determine the grain yield and perform the analysis of their chemical composition, pods or ears were sampled from plants spaced $10 \mathrm{~m}$ apart, in the three center rows, resulting in an effectively harvested area of $13.5 \mathrm{~m}^{2}$. The pods or ears were dried to $13 \%$ moisture and threshed and the seeds were cleaned before weighing. Subsamples of $200 \mathrm{~g}$ of seeds were sorted for chemical analysis. After being dried at $70{ }^{\circ} \mathrm{C}$, seeds were powdered in a Willey Mill to $1.0 \mathrm{~mm}$ mesh size, and the macronutrient content was determined by standard analytical methods (Sparks et al, 1996).

The statistical analysis of the soil attributes, at each depth, crop productivity and the nutrient export data was performed using SISVAR (version 5.1) statisti- 
cal software. The data was subjected to analysis of variance (ANOVA) and where ANOVA showed significant differences, Tukey's test with a probability of $5 \%$ was used to separate the means. The results obtained about organic matter $(\mathrm{OM}), \mathrm{pH}$, evaluable $\mathrm{P}$ and $\mathrm{K}$, cation exchange capacity and base saturation were plotted in graphics that show the changes in the soil chemical attributes throughout the period under study. Significant differences were shown when main effects or interactions between tillage and fertilization systems occurred. In some cases there were also horizontal lines representing critical or reference levels of nutrients, according to the Fertilization and Liming Committee (2004). Additionally, in a number of plots there was a gap in the line of NT, at the $10-20 \mathrm{~cm}$ depth, due to the impossibility of sampling the soil because of its low moisture content.

\section{Results and Discussion}

\section{Soil chemical attributes}

\section{Organic matter}

The level of organic matter in the soil was affected by tillage systems, depending on soil layer and sampling time (Figure 1). In all tillage systems, contents of OM were highest at the $0-5 \mathrm{~cm}$ layer and the lowest values were found at the $10-20 \mathrm{~cm}$ layer. However, under CT the differences were less and the OM content decreased more gradually in the soil profile. Additionally, within the $0-5 \mathrm{~cm}$ layer, OM content was the lowest under this tillage system, in comparison to RT and especially to NT, which showed the greatest value. The tillage systems did not differ within the $5-10 \mathrm{~cm}$ and $10-20 \mathrm{~cm}$ layers.

Although oscillations have been observed during the period of the experiment, the effect of tillage systems was clearly observed. Since the beginning of the experiment, NT management resulted in a gradual increase in soil $\mathrm{OM}$ at the soil surface, being superior to other tillage systems from the $40^{\text {th }}$ month onward. In contrast, CT tended to decrease the OM content, resulting in values lower than those obtained under the other tillage systems and even lower than the original ones. In its turn, RT had an intermediate behavior between $\mathrm{CT}$ and NT, with a slight trend toward increasing organic matter content.

The dynamics of OM observed under NT can be attributed to the lack of soil disturbance and the maintenance of crop residues on the soil surface, which results in a gradual increase in the OM content in the soil surface layers. On the other hand, soil management practices that promote soil disturbance favor the loss of OM. Conceição et al. (2013) and Tan and Lal (2005) evidenced the improvement in OM content of the surface layers in NT. On the other hand, the rates of OM decomposition increase as the soil disturbance increases, leading to a decline in this soil attribute (Bayer et al., 2000; Panettieri et al., 2013), so that the OM content, over the years, is inversely proportional to the intensity of soil disturbance caused by the different tillage practices.

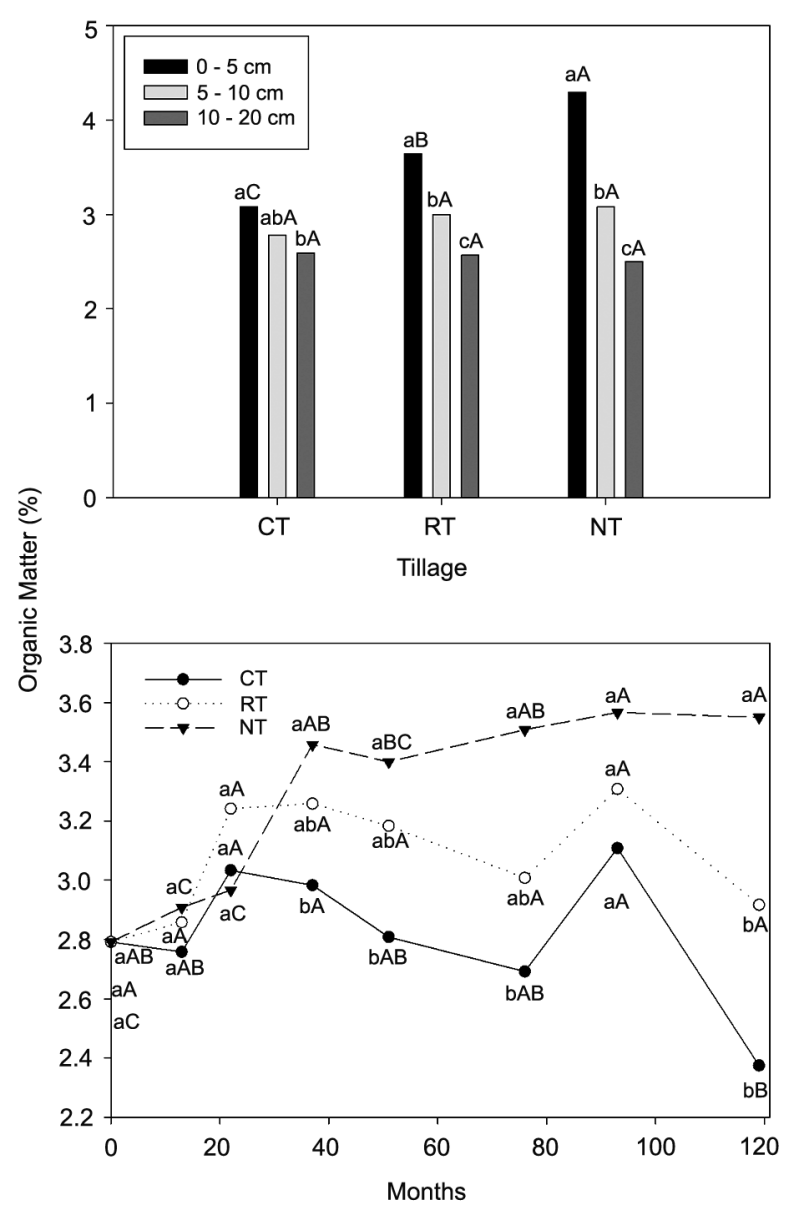

Figure 1 - Organic matter content in a soil under different management systems, at three layer depth intervals, over ten years. Lowercase letters compare the depth layer intervals under each tillage system or tillage systems at each sampling time and capital letters compare tillage systems at each layer depth interval or sampling times under each tillage system. Means followed by the same letter are not different (Tukey, $p<0.05$ ). CT = conventional tillage; $\mathrm{RT}=$ reduced tillage; NT $=$ no-tillage.

\section{Soil pH}

With regard to the $\mathrm{pH}$ values, there was a significant interaction of tillage, soil layer and sampling time and a significant interaction of fertilization and sampling time (Figure 2). There was a marked initial increase in soil $\mathrm{pH}$ of plots under mineral fertilization, to which lime was applied, as compared to plots under organic fertilization with no lime added.

When comparing tillage systems, regardless of fertilization, the greatest differences were observed in the $0-5 \mathrm{~cm}$ layer, with NT being superior in almost all the sampling times. Under this kind of tillage, only a slight disturbance is expected to occur, with some incorporation of lime in the seed row. Thus, as verified for $\mathrm{OM}, \mathrm{NT}$ had the greatest $\mathrm{pH}$ values, more notably in the surface layer, due to the lack of soil disturbance and 

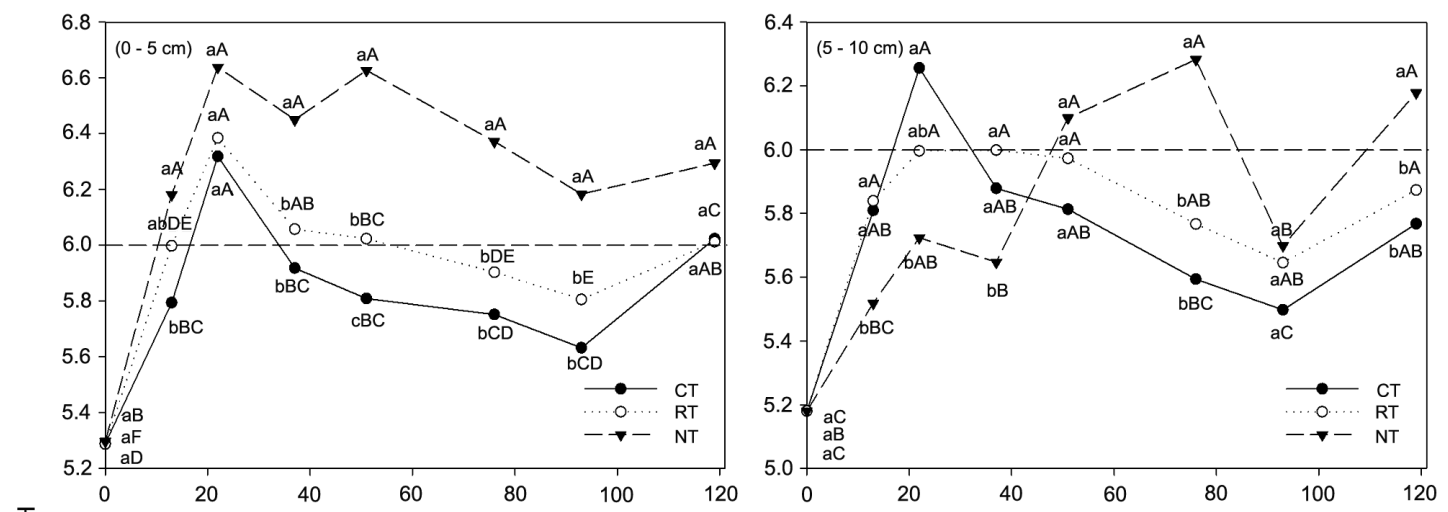

I
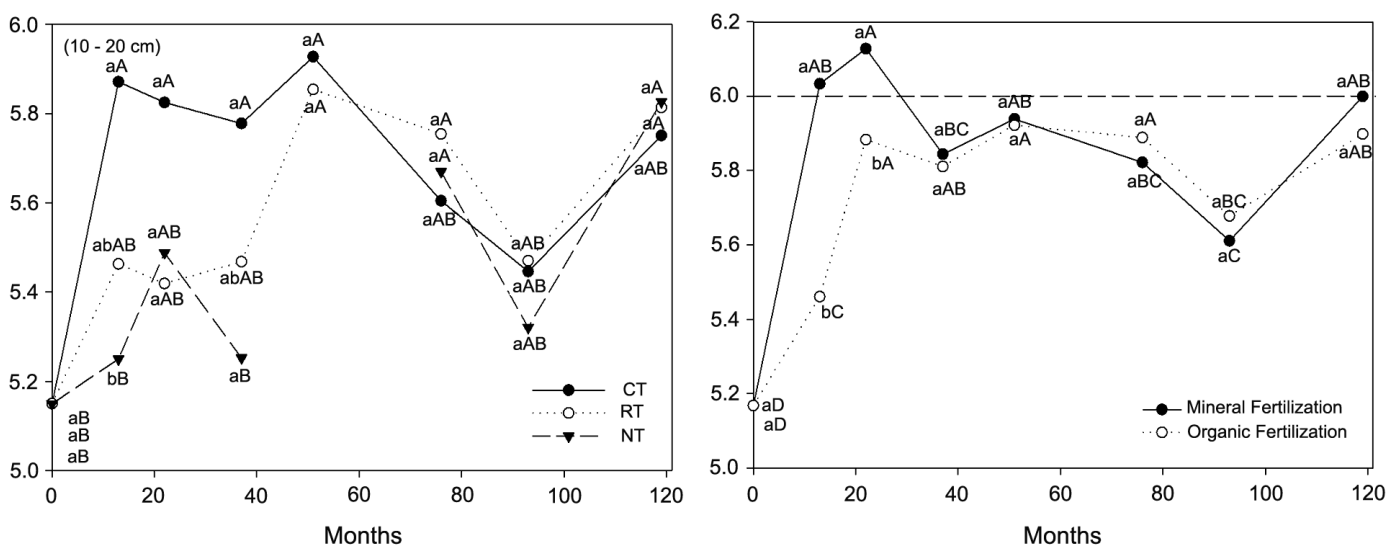

Figure 2 - Values of pH in a soil under different tillage and fertilization systems, at three layer depth intervals, over ten years. Lowercase letters compare tillage systems at each layer depth interval and each sampling time or compare fertilization systems. Capital letters compare sampling times. Means followed by the same letter are not different (Tukey, $p<0.05$ ). CT = conventional tillage; RT = reduced tillage; NT = no-tillage.

because of the tendency of the lime and the products of its reaction to stay close to the soil surface because alkalinity must be transported from the surface by mass flow to lower layers (Wyngaard et al., 2012).

In deeper layers, $\mathrm{pH}$ increased more rapidly under CT and RT than under NT. Those two tillage systems also had less variation in $\mathrm{pH}$ values between the layer depths caused by the incorporation of lime, distributing it deeper in the soil profile and ameliorating a greater volume of soil. Nonetheless, by approximately the 80th month, the residual effect of lime and poultry litter was more pronounced under NT in deeper layers, especially at $5-10 \mathrm{~cm}$.

In the deepest layer $(10-20 \mathrm{~cm})$, the values of $\mathrm{pH}$ under NT were inferior to the values observed in the other tillage systems, in most of the sampling times. But again after the 80th month, the differences were not significant, so that the three tillage systems had very similar $\mathrm{pH}$ values, evidencing an decrease in acidity over time in the deeper soil layers. Similar results were reported by Caires et al. (2005), studying the effects of surface liming on NT. The authors verified the occurrence of a quick ef- fect up to a depth of $10 \mathrm{~cm}$ and a slower effect at deeper depths. Likewise, Caires et al. (2006) noted that acidity neutralization with surface liming occurred linearly over five years, showing that the reaction of surface-applied lime is slow and gradual. Thus, there is an initial limited effect of surface liming, which is, however, compensated for by its long-term effect under NT, especially in the deeper layers.

The depth effect of liming under NT is caused by the translocation of thin particles of limestone through soil channels, by the formation of complexes among water-soluble organic compounds and $\mathrm{Ca}$ and $\mathrm{Mg}$ at the soil surface and the subsequent exchange of these cations by $\mathrm{Al}$ at deeper layers, as well as the production of non-toxic stable complexes formed by the soil OM and the aluminum (Ernani et al., 2004; Gómez-Paccard et al., 2013; Miyazawa et al., 2002; Oliveira and Pavan, 1996; Roth and Pavan, 1991). In the case of poultry litter, similar mechanisms of translocation of particles and reaction products are expected to occur, since this residue is rich in calcium carbonates and phosphates, in addition to allowing for the formation of water-soluble organic 
compounds that can complex $\mathrm{Ca}$ and $\mathrm{Mg}$ and transport them through the soil profile (Hue and Licudine, 1999).

With regard to the residual effect of both limestone as well as poultry litter in relation to soil acidity, under $\mathrm{CT}$ and RT the $\mathrm{pH}$ values were close to 6 or even higher, in the $0-5$ and $5-10 \mathrm{~cm}$ layers, up to the $50^{\text {th }}$ month, tending to decrease later on. However, under $\mathrm{NT}, \mathrm{pH}$ values were always higher than 6.0 in the surface layer during the whole experiment period and, in general, after the $50^{\text {th }}$ month in the 5-10 cm layer. In the inferior layer, $\mathrm{pH}$ values higher than 6.0 were not reached.

\section{Available phosphorus}

The level of available phosphorus (Mehlich-1 P) in the soil was influenced by the tillage methods as well as by the fertilization systems, soil layer and sampling time (Figure 3). As a rule, during the experimental period, organic fertilization resulted in higher levels of $\mathrm{P}$ than mineral fertilization, as a result of the large input of this nutrient, due to the criteria used to establish the doses of organic fertilizer. When maize was cultivated, the dose of poultry litter was calculated based on the demand for $\mathrm{N}$, resulting in a dose of $\mathrm{P}$ higher than that applied via mineral fertilization.

In the last sampling times, there was a general trend of decreasing soil $\mathrm{P}$ levels, as compared to the previous sampling date. Considering the mineral fertilization treatment, it can indicate that the $\mathrm{P}$ replacement rates were lower than plant uptake and soil adsorption. In addition to this, in the case of the organic fertilization, the decreasing soil $\mathrm{P}$ levels, although still over the critical value, can also be attributed to the interruption of the input of poultry litter from the $90^{\text {th }}$ month onward, as previously reported.

In relation to soil tillage systems, in the surface layer, NT and RT with organic fertilization stood out from the other treatments. Phosphorus accumulation is favored by minimal soil disturbance, because this condition diminishes the contact surface between adsorption sites and phosphate ions, thereby increasing $\mathrm{P}$ availability in soil (Hedley et al., 1982; Selles et al., 1997). Other advantages of NT and RT over CT, in terms of P avail-
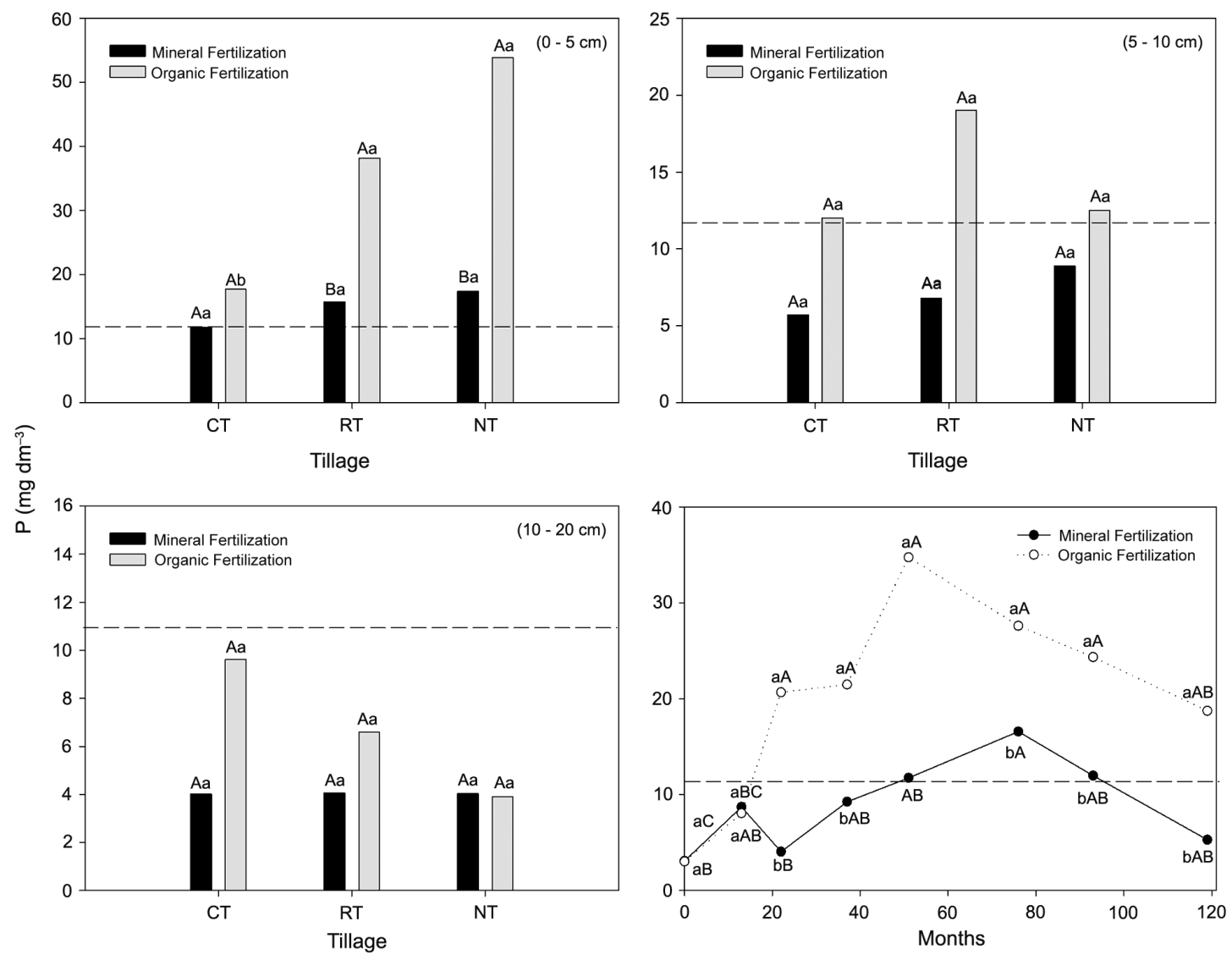

Figure 3 - Phosphorus values in a soil under different tillage and fertilization systems, at three layer depth intervals, over ten years. At each depth interval, lowercase letters compare tillage systems in each fertilization system and capital letters compare fertilization systems in each tillage system. Throughout the period, lowercase letters compare fertilization systems at each sampling time and capital letters sampling times under each fertilization system. Means followed by the same letter are not different (Tukey, $p<0.05$ ). $\mathrm{CT}=$ conventional tillage; RT = reduced tillage; NT = no-tillage. 
ability, are related to the reduction of soil erosion, the accumulation of labile forms of $\mathrm{P}$ derived from the presence of organic residues in the soil (Selles et al., 1997) and to the effect of OM negative charges maintaining freely available phosphate (Sá et al., 2009). Therefore, the combination of conservation tillage and $\mathrm{P}$ fertilization is expected to improve soil $\mathrm{P}$ supplying capacity (Shi et al., 2013).

In the deepest layer the levels of $\mathrm{P}$ were reduced under both NT and RT, with no difference under CT. In this $10-20 \mathrm{~cm}$ layer, under both fertilizer systems and every tillage system, available $\mathrm{P}$ was below the critical level. These results are in agreement with Lal et al. (1990), who found higher concentrations of P in NT up to a depth of $10 \mathrm{~cm}$ in a 12-year long experiment.

\section{Available potassium}

In general terms, soil $\mathrm{K}$ levels fluctuated during the experimental period, regardless of treatment or sampling depth (Figure 4). However, the values found were always higher than the critical level for this soil $160 \mathrm{mg}$ $\mathrm{dm}^{-3}$ ), being considered as high or very high levels (Fertilization and Liming Committee, 2004). Since this soil is derived from granite, it is naturally rich in $\mathrm{K}$. The observed fluctuations can be credited to $\mathrm{K}$ recycling in the soil-plant system, with uptake in deeper layers, deposition in surface and removal by plants or leaching.

The levels of $\mathrm{K}$ in soil were always superior $(p<$ 0.05 ) at the $0-5 \mathrm{~cm}$ layer, since the beginning of the experiment. The hypothesis of accumulation of $\mathrm{K}$ in the surface due to the recycling by plants is supported by the increase of $\mathrm{K}$ content even without the application of nutrient at most of the times. As $\mathrm{K}$ occurs in free cationic form in plant tissues, it is easily lost by leaching in the late growth stages, when leaves and roots are senescing, as observed by Ning et al. (2013). Also Peng et al. (2012) found a $\mathrm{K}$ increase $(p<0.05)$ in the maize rhizosphere, which was consistent with net $\mathrm{K}$ loss from plants in the late reproductive growth stage.

When comparing tillage systems, CT exhibited greater values than NT, although differences were found $(p<0.05)$ only in some periods. Mina et al. (2008) detected a higher concentration of $\mathrm{K}$ in the surface layer under NT. In a similar way, Sá et al. (2009) verified a higher concentration of $\mathrm{K}$ in $\mathrm{NT}$, assigning it to the impact of large amounts of $\mathrm{K}$ rich crop residues and to the increase in soil OM, which increased CEC and led to retention of $\mathrm{K}$ in the soil, contradicting our results. On the other hand Bertol et al. (2007) found greater losses of $\mathrm{K}$ in runoff water from NT than from $\mathrm{CT}$, which could explain the results obtained in the present research.

The organic fertilization resulted in the greatest levels of $\mathrm{K}$ in the soil, from the third sampling, due to the larger inputs of nutrient in this treatment over time. Agbede and Ojeniyi (2009) also observed the increase in soil $\mathrm{K}$ levels with the application of poultry manure, irrespective of the tillage treatment. Based on the levels of $K$, there would be no need for fertilization, un- less it were for replacing the amount removed by plants. However, organic fertilization was established based on demand by $\mathrm{N}$ or $\mathrm{P}$, so that $\mathrm{K}$ was applied as an accompanying nutrient.
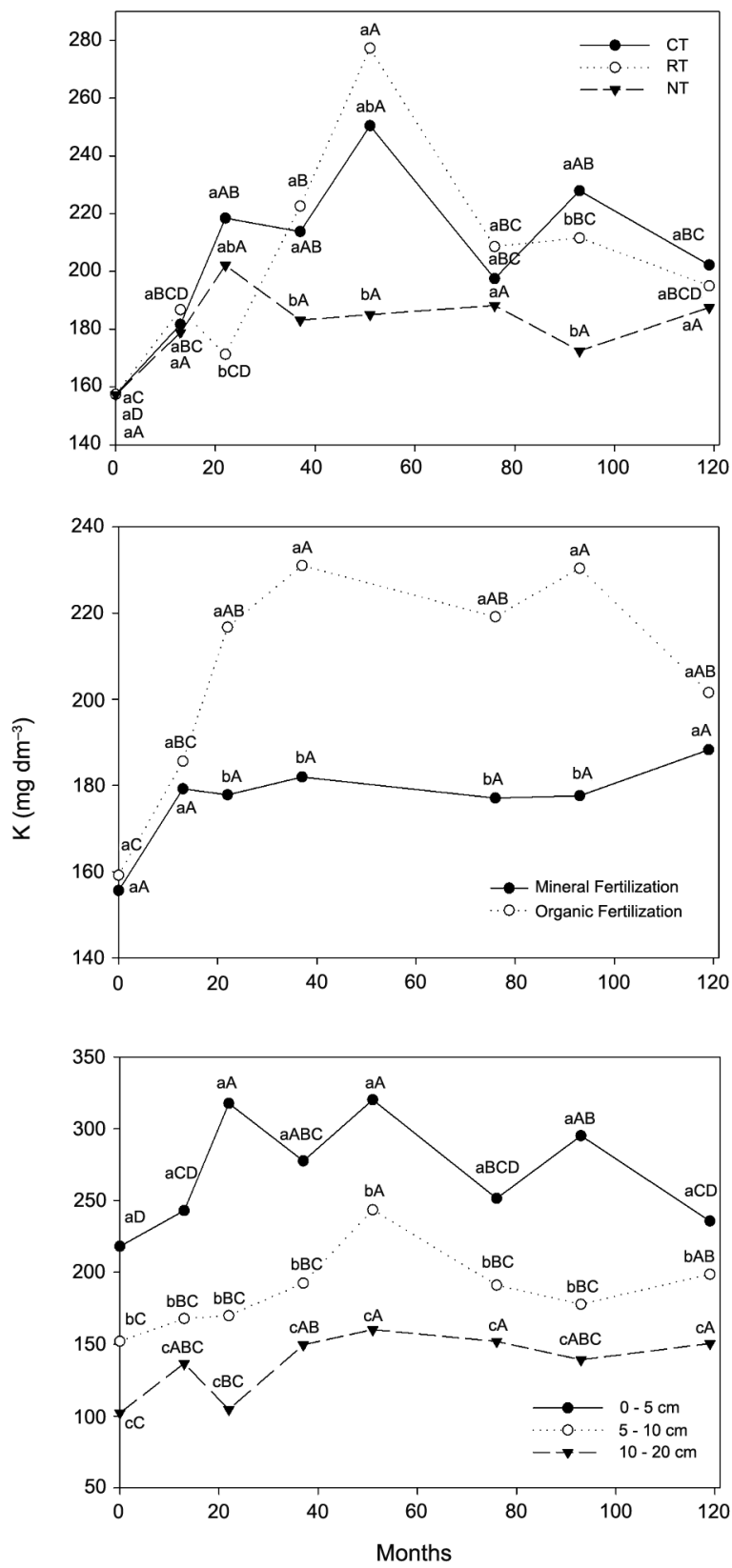

Figure 4 - Potassium values in a soil under different tillage and fertilization systems, at three layer depth intervals, over ten years. Lowercase letters compare tillage systems, fertilization systems or layer depth intervals at each sampling time and capital letters compare sampling times. Means followed by the same letter, at each layer depth interval and each sampling time, are not different (Tukey, $p<0.05$ ). CT = conventional tillage; RT = reduced tillage; NT $=$ no-tillage. 


\section{Cation exchange capacity}

CEC values were high $\left(>15.0 \mathrm{cmol}_{\mathrm{c}} \mathrm{dm}^{-3}\right)$ on only one occasion, around the $80^{\text {th }}$ month, in $\mathrm{NT}$, at the $0-5$ $\mathrm{cm}$ layer, and were considered as medium (5.1 - 15.0 $\mathrm{cmol}_{\mathrm{c}} \mathrm{dm}^{-3}$ ) in all other cases (Figure 5), according to the criteria of the Fertilization and Liming Committee (2004).

Comparing the tillage systems, NT and RT had the greatest values of CEC, usually surpassing the values of CT. This was observed from the very beginning of the experiment at the $0-5 \mathrm{~cm}$ layer and from the $40^{\text {th }}$ month at $5-10 \mathrm{~cm}$. The values of CEC under NT and RT are related to the OM content in these tillage systems, since OM accounts for a major part of the variable negative charges, resulting in the increase of soil CEC. At the 10$20 \mathrm{~cm}$ layer, in most of the experimental period, the tillage systems were almost equal with regard to this soil attribute.

As time passed, CEC tended to increase up to about the $80^{\text {th }}$ month, regardless of treatment or layer depth. As well as the OM, the increase in CEC may also be imputed to the increase in soil pH (Sá et al., 2009) during part of the experiment. The decline in soil $\mathrm{pH}$ during the last months of the experiment is related to the vanishing of the residual effect of liming and to the interruption of organic fertilization, which resulted in the decrease of soil $\mathrm{pH}$, soil $\mathrm{OM}$ and, as a consequence, soil CEC. In the present research, a positive correlation was observed between OM and CEC $(\mathrm{r}=0.6645 ; p<0.01)$, which agrees with the results obtained by Vieira et al. (2007), who found positive correlations between CEC and the carbon management index in another long-term experiment on the same kind of soil.

\section{Base saturation}

Over the years, base saturation values showed a trend similar to $\mathrm{pH}$ values, so that there was positive correlation between the two variables $\mid \mathrm{r}=0.8874 ; p<$ 0.01). Positive correlation between these two variables has been reported by several authors (Beery and Wilding, 1971; Caires et al., 2006; Liechty et al., 2005). It is expected, with the increase in soil $\mathrm{pH}$, that $\mathrm{Al}^{3+}$ precipitates, CEC increases and exchange sites be occupied by $\mathrm{Ca}_{2}{ }^{+}$and $\mathrm{Mg}^{2+}$ released from lime or organic fertilizer (Martins et al., 2014; Matschonat and Falkengren-Grerup, 2000). Conversely, $\mathrm{pH}$ will drop when base saturation of the exchange complex is depleted (Roelofs et al., 1996).

From the 50th month onward, NT had base saturation values greater than RT and CT (Figure 6). Likewise, De Maria et al. (1999) also found higher values of base saturation under NT in comparison to CT. So, the greatest values of base saturation in NT can be attributed to the accumulation of $\mathrm{Ca}$ and $\mathrm{Mg}$ close to the soil surface, derived from lime and poultry litter, besides the absence of exchangeable $\mathrm{Al}$ and the high levels of $\mathrm{K}$ verified throughout the experimental period.
As regards soil depth, base saturation was always higher at the $0-5 \mathrm{~cm}$ layer regardless of tillage or fertilization, and the highest values were found in the $13^{\text {th }}$ month at the three soil layers. Thus, base saturation val-
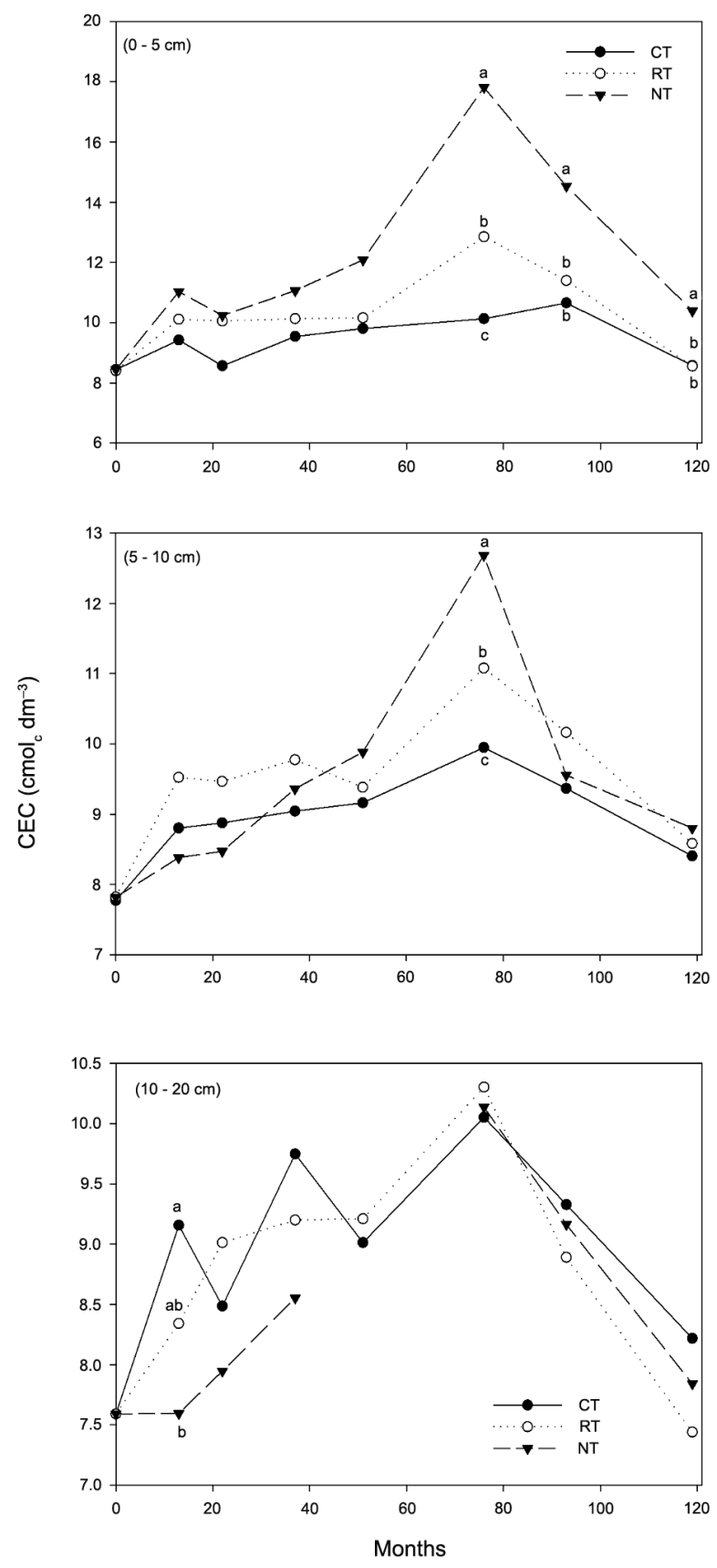

Figure 5 - Cation exchange capacity (CEC) at pH 7.0 in a soil under different tillage systems, at three layer depth intervals, over ten years. Means followed by the same letter, at each layer depth interval and each sampling time, are not different (Tukey, $p<$ 0.05). $\mathrm{CT}=$ conventional tillage; $\mathrm{RT}=$ reduced tillage; $\mathrm{NT}=$ notillage. 


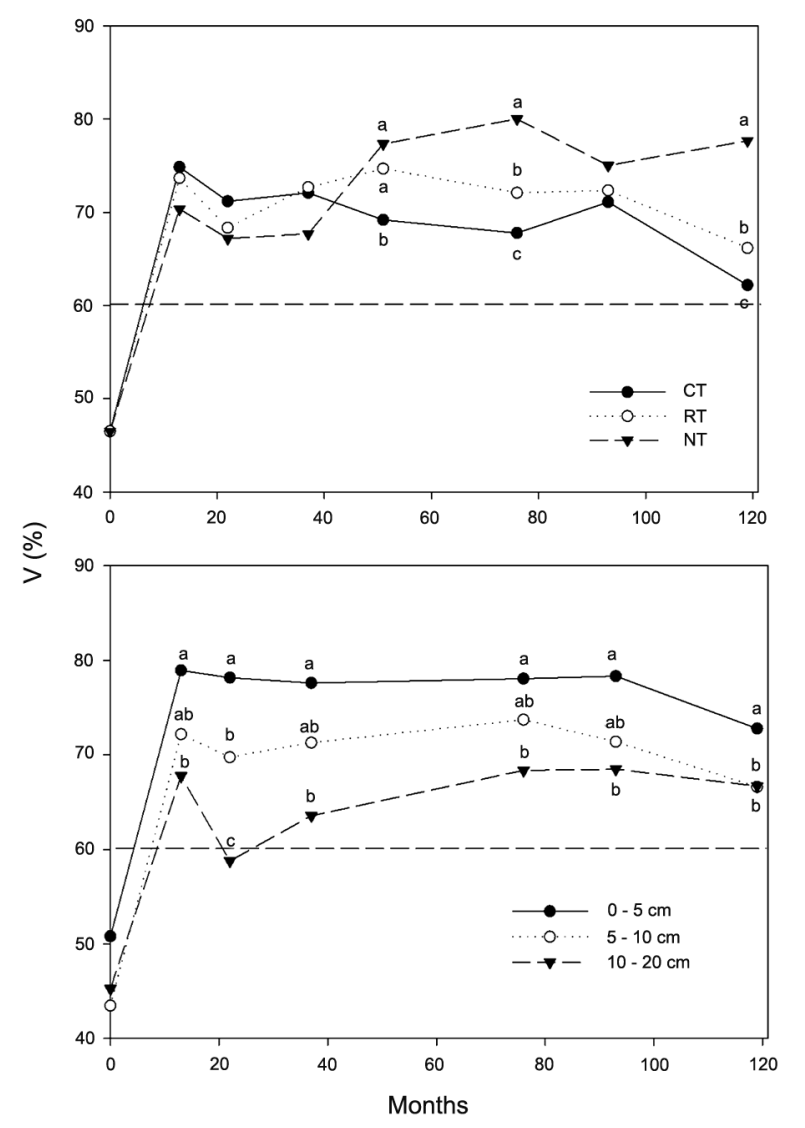

Figure 6 - Base saturation values in a soil under different tillage systems, at three layer depth intervals, over ten years. At each sampling time, lowercase letters compare tillage systems or layer depth interval. Means followed by the same letter are not different (Tukey, $p<0.05$ ). CT = conventional tillage; RT = reduced tillage; NT $=$ no-tillage.

ues followed the same trend as $\mathrm{K}$ and $\mathrm{pH}$. The decrease in soil $\mathrm{pH}$ must have allowed the downward movement of $\mathrm{H}^{+}$and soluble $\mathrm{Al}$ (Hue and Licudine, 1999) which occupied the exchange sites, a process that, associated with the decrease in $\mathrm{K}$ levels, resulted in lower base saturation in the subsurface.

Considering the whole experimental period, base saturation values were $60 \%$ greater after the application of organic or mineral fertilization in all soil layers and almost all the sampling times, with soil $\mathrm{pH}$ 6.0 corresponding to an average value of about $70 \%$ of base saturation. As values between 60 and $80 \%$ are considered as medium (Fertilization and Liming Committee, 2004), it is possible to conclude that all tillage and fertilizer treatments were equally efficient at providing adequate chemical conditions for root development up to the sampling depth throughout the experiment.

\section{Crop productivity}

The soybean yield was relatively low in all treatments, particularly under NT, whose average yield was $1,412 \mathrm{~kg} \mathrm{ha}^{-1}$, lower than RT and CT $(p<0.05)$, which did not differ between them, having yields of $2,324.5$ and $2,108.5 \mathrm{~kg} \mathrm{ha}^{-1}$, respectively. The fertilization systems did not affect the yield under any of the tillage treatments. In its turn, the maize yield was relatively high, with no differences $(p<0.05)$ between the three tillage systems. Equally, there was no effect of fertilization, so that the average yield was 6,992.3 $\mathrm{kg} \mathrm{ha}{ }^{-1}$.

Other authors also found no effect of tillage (Hussaina et al., 1999) on maize yield or lower soybean yield in NT (Freed et al., 1987). However, lower yields generally occur only during the stabilization phase of the NT. From the $5^{\text {th }}$ year on, in view of the improvement in the chemical, physical and biological properties of the soil arising from the use of NT, higher crop yields would be expected under this tillage system (Franchini et al., 2012), which is in opposition to what we found.

If crop yields are not increased by NT, it implies that something is failing at a given stage or process within the agricultural system (Derpsch et al., 2014). Soil compression has often been suggested as a major cause of decline in the yield of rainfed crops, as a consequence of the changes in root environment, resulting in low oxygen and water availability and increasing soil resistance to root growth, notably under water deficiency (Chen and Weil, 2011). As the current experiment was installed directly over natural vegetation, a higher soil bulk density is likely to have occurred under NT (Alvarez and Steinbach, 2009), affecting root development and crop yield. Subsurface acidity is another usual constraint under NT (Conyers et al., 2003) that may also have accounted for the poor performance of this system in terms of crop yield.

\section{Nutrient export}

The export of nutrients ( $\mathrm{N}, \mathrm{P}, \mathrm{K}, \mathrm{Ca}$ and $\mathrm{Mg}$ ) by soybean was lower under NT $(p<0.05)$, in comparison to RT and CT, for both fertilizer systems (Figure 7). This result is linked to the lower soybean yield in NT, which directly affected the amount of nutrients in the grains. Fertilization systems did not affect nutrient export by soybean, indicating similar availability and uptake under both systems. The amount of nutrients exported as soybean grain yield followed the sequence $\mathrm{N}>>\mathrm{K}>\mathrm{P}>\mathrm{Ca}>\mathrm{Mg}$.

Since the yield of maize is higher than that of soybean, nutrient export by maize was also higher (Figure 8). The only exception was $\mathrm{Ca}$, because, in general, legumes have higher $\mathrm{Ca}$ content than grasses (Hinsinger and Gilkes, 1997; Li et al., 2004; Volz and Jacobson, 1977) and, soybean plants, in particular, are more efficient than maize plants in terms of Ca uptake from soil solution (Caires et al., 2011). Maize nutrient export was not influenced $(p<0.05)$ by the tillage or the fertiliza- 

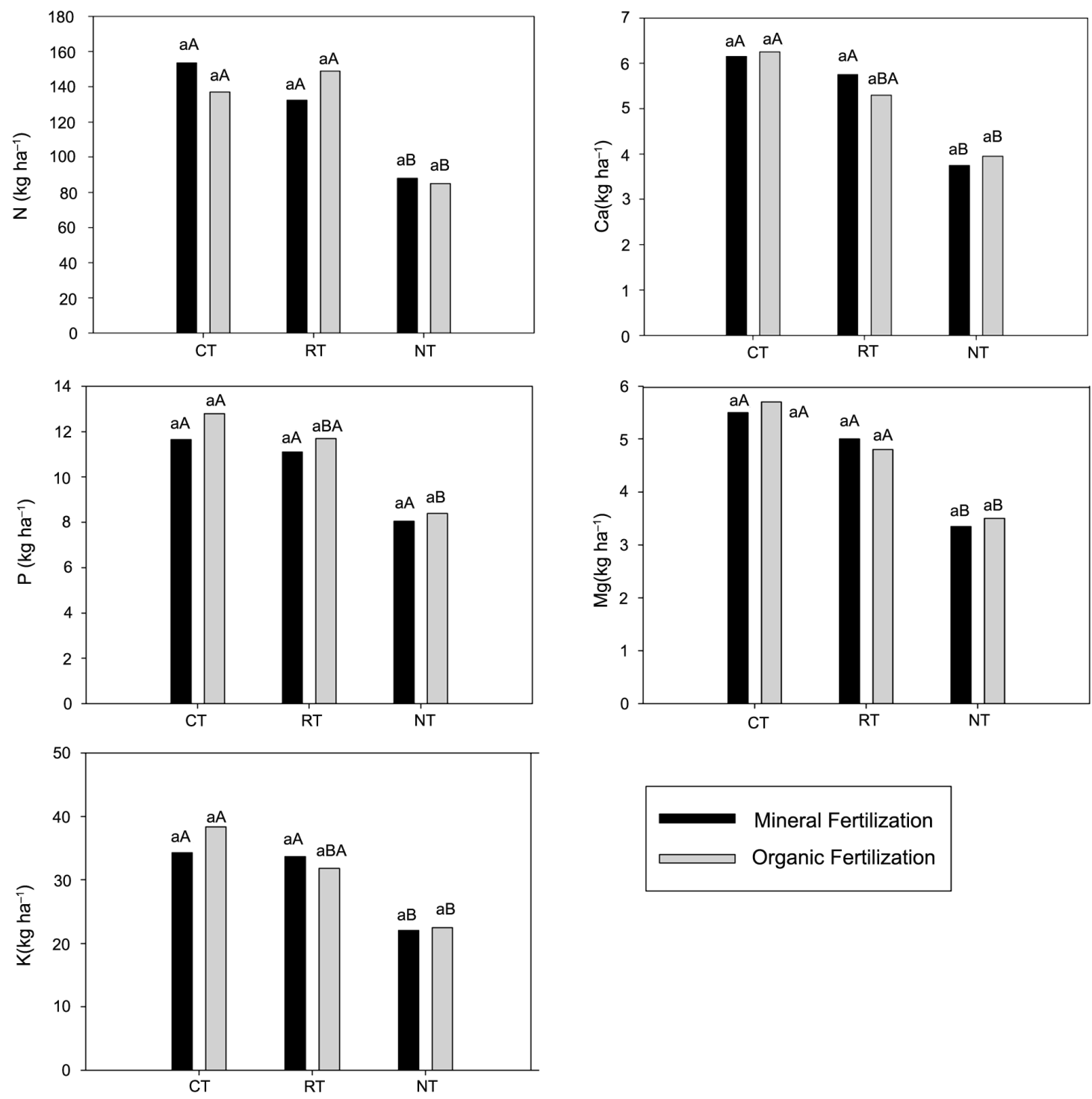

Figure 7 - Amount of nutrients exported by soybean (2007/2008) in a soil under different tillage and fertilization systems. Lowercase letters compare fertilization systems and capital letters compare tillage systems. Means followed by the same letter are not different (Tukey, $p<$ 0.05). CT = conventional tillage; RT = reduced tillage; NT = no-tillage.

tion treatments. In this crop, the sequence of nutrient export was $\mathrm{N}>>\mathrm{K}>\mathrm{P}>\mathrm{Mg}>>\mathrm{Ca}$. The greatest difference between soybean and maize was the highest accumulation of $\mathrm{Ca}$ by the legume, even though the grain yield was much lower than that of maize.

Taking into account the rates of maintenance fertilization with NPK for soybean and maize, according to the Fertilization and Liming Committee (2004), it is possible to conclude that they are compatible with the rates of nutrient export by plants verified in the present research for soybean under mineral fertilization and for maize under organic fertilization. In the other situations, for soybean under organic fertilization and for maize under mineral fertilization, in order to supply the amount of nutrient export, according to reference yield values established by the Fertilization and Liming Committee (2004), fertilizer should be applied in higher rates, as compared to maintenance fertilization for these crops.

As a conclusion, chemical attributes changed over the course of ten years of soil management. Tillage systems influenced the analyzed attributes more intensely than fertilization. NT improved soil OM, pH, $\mathrm{P}, \mathrm{CEC}$ and base saturation, prevailing over the other tillages, especially in the surface layer. Despite this, crop yields did not increase under NT, indicating that some physical or even chemical constraint, probably in the subsurface, may have counterbalanced the positive effects of this system. 

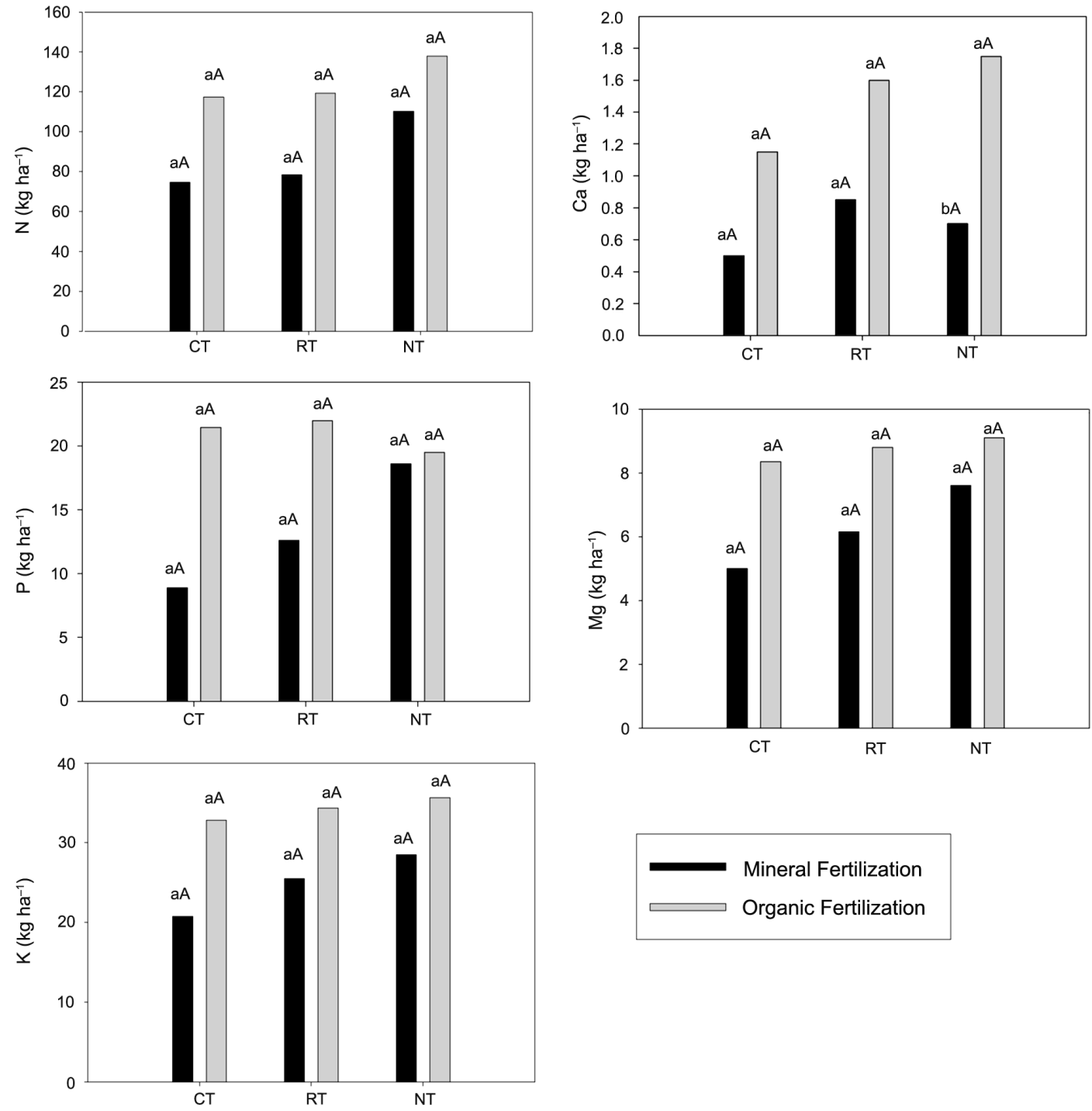

Figure 8 - Amount of nutrients exported by maize (2008/2009) in a soil under different tillage and fertilization systems. Lowercase letters compare fertilization systems and capital letters compare tillage systems. Means followed by the same letter are not different (Tukey, $p<$ 0.05). $\mathrm{CT}=$ conventional tillage; RT = reduced tillage; NT = no-tillage.

\section{References}

Agbede, T.M.; Ojeniyi, S.O. 2009. Tillage and poultry manure effects on soil fertility and sorghum yield in southwestern Nigeria. Soil and Tillage Research 104: 74-81.

Akaike, H. 1974 A new look at the statistical model identification. IEEE Transactions on Automatic Control 19: 716-723.

Alvarez, R.; Steinbach, H.S. 2009. A review of the effects of tillage systems on some soil physical properties, water content, nitrate availability and crops yield in the Argentine Pampas. Soil and Tillage Research 104: 1-15.

Bayer, C.; Mielniczuk, J.; Amado, T.J.C.; Martin-Neto, L.; Fernandes, S.V. 2000. Organic matter storage in a sandy clay loam Acrisol affected by tillage and cropping systems in southern Brazil. Soil and Tillage Research 54: 101-109.
Beery, M.; Wilding, L.P. 1971. The Relationship between soil $\mathrm{pH}$ and base-saturation percentage for surface and subsoil horizons of selected Mollisols, Alfisols, and Ultisols in Ohio. The Ohio Journal of Science 71: 43-55.

Bergamaschi, H.; Guadagnin, M.R. 1990. Agroclimate of Agronomic Experimental Station = Agroclima da Estação Experimental Agronômica. Universidade Federal do Rio Grande do Sul, Porto Alegre, RS, Brazil (in Portuguese).

Bertol, I.; Engel, F.L.; Mafra, A.L.; Bertol, O.J.; Ritter, S.R. 2007. Phosphorus, potassium and organic carbon concentrations in runoff water and sediments under different soil tillage systems during soybean growth. Soil and Tillage Research 94: 142-150.

Bizarro, M.J.; Giongo, A.; Vargas, L.K.; Roesch, L.F.W.; Gano, K.A.; Sá, E.L.S.; Passaglia, L.M.P.; Selbach, P.A. 2011. Genetic variability of soybean bradyrhizobia populations under different 
soil managements. Biology and Fertility of Soils 47: 357-362.

Caires, E.F.; Alleoni, L.R.F.; Cambri, M.A.; Barth, G. 2005. Surface application of lime for crop grain production under a no-till system. Agronomy Journal 97: 791-798.

Caires, E.F.; Barth, G.; Garbuio, F.J. 2006. Lime application in the establishment of a no-till system for grain crop production in Southern Brazil. Soil and Tillage Research 89: 3-12.

Caires, E.F.; Joris, H.A.W.; Churka, S. 2011. Long-term effects of lime and gypsum additions on no-till corn and soybean yield and soil chemical properties in southern Brazil. Soil Use and Management 27: 45-53.

Chen, G.; Weil, R.R. 2011. Root growth and yield of maize as affected by soil compaction and cover crops. Soil and Tillage Research 117: 17-27.

Conceição, P.C.; Dieckow, J.; Bayer, C. 2013. Combined role of no-tillage and cropping systems in soil carbon stocks and stabilization. Soil and Tillage Research 129: 40-47.

Conyers, M.K.; Heenan, D.P.; McGhie, W.J.; Poile, G.P. 2003. Amelioration of acidity with time by limestone under contrasting tillage. Soil and Tillage Research 72: 85-94.

Costa, S.E.V.G.A.; Souza, E.D.; Anghinoni, I.; Flores, J.P.C.; Vieira, F.C.B.; Martins, A.P.; Ferreira, E.V.O. 2010. Patterns in phosphorus and corn root distribution and yield in long-term tillage systems with fertilizer application. Soil and Tillage Research 109: 41-49.

De Maria, I.C.; Nnabude, P.C.; de Castro, O.M. 1999. Long-term tillage and crop rotation effects on soil chemical properties of a Rhodic Ferralsol in southern Brazil. Soil and Tillage Research 51: 71-79.

Derpsch, R.; Franzluebbers, A.J.; Duiker, S.W.; Reicosky, D.C.; Koeller, K.; Friedrich, T.; Sturny, W.G.; Sá, J.C.M.; Weiss, K. 2014. Why do we need to standardize no-tillage research? Soil and Tillage Research 137: 16-22.

Ernani, P.R.; Ribeiro, M.F.S.; Bayer, C. 2004. Chemical modifications caused by liming below the limed layer in a predominantly variable charge acid soil. Communications in Soil Science and Plant Analysis 35: 889-901.

Ferreira, A.O.; Amado, T.J.C.; Nicoloso, R.S.; Sá, J.C.M.; Fiorin, J.E.; Hansel, D.S.S.; Menefee, D. 2013. Soil carbon stratification affected by long-term tillage and cropping systems in southern Brazil. Soil and Tillage Research 133: 65-74.

Fertilization and Liming Committee. 1995. Fertilization Committee of Soil from the States of Rio Grande do Sul and Santa Catarina = Recomendações de Adubação e Calagem para os Estados do Rio Grande do Sul e Santa Catarina. SBSC/Embrapa, Passo Fundo, RS, Brazil (in Portuguese).

Fertilization and Liming Committee. 2004. Fertilization Committee of Soil from the States of Rio Grande do Sul and Santa Catarina = Recomendações de Adubação e Calagem para os Estados do Rio Grande do Sul e Santa Catarina. SBSC, Porto Alegre, RS, Brazil (in Portuguese).

Franchini, J.C.; Debiasi, H.; Balbinot Junior, A.A.; Tonon, B.C.; Farias, J.R.B.; Oliveira, M.C.N.; Torres, E. 2012. Evolution of crop yields in different tillage and cropping systems over two decades in southern Brazil. Field Crops Research 137: 178-185.

Freed, B.E.; Oplinger, E.S.; Buhler, D.D. 1987. Velvetleaf control for solid-seeded soybean in three corn residue management systems. Agronomy Journal 79: 119-123.
Gómez-Paccard, C.; Mariscal-Sancho, I.; León, P.; Benito, M.; González, P.; Ordóñez, R.; Espejo, R.; Hontoria, C. 2013. Caamendment and tillage: medium term synergies for improving key soil properties of acid soils. Soil and Tillage Research 134: 195-206.

Hedley, M.J.; Stewart, J.W.B.; Chauhan, B.S. 1982. Changes in inorganic and organic soil phosphorus fractions induced by cultivation practices and by laboratory incubations. Soil Science Society of America Journal 46: 970-976.

Hinsinger, P.; Gilkes, R.J. 1997. Dissolution of phosphate rock in the rhizosphere of five plant species grown in an acid, P-fixing mineral substrate. Geoderma 75: 231-249.

Hue, N.V.; Licudine, D.L. 1999. Amelioration of subsoil acidity through surface application of organic manures. Journal of Environmental Quality 28: 623-632.

Hussaina, I.; Olsonb, K.R; Ebelharc, S.A. 1999. Impacts of tillage and no-till on production of maize and soybean on an eroded Illinois silt loam soil. Soil and Tillage Research 52: 37-49.

Lal, R.; Logan, T.J.; Fausey, N.R. 1990. Long-term tillage effects on a Mollic Ochraqualf in north west Ohio: III. Soil nutrient profile. Soil and Tillage Research 15: 371-382.

Li, L.; Tang, C.; Rengel, Z.; Zhang, F.S. 2004. Calcium, magnesium and microelement uptake as affected by phosphorus sources and interspecific root interactions between wheat and chickpea. Plant and Soil 261: 29-37.

Liechty, H.O.; Luckow, K.R.; Guldin, J.M. 2005. Soil chemistry and nutrient regimes following 17-21 years of shortleaf pinebluestem restoration in the Ouachita Mountains of Arkansas. Forest Ecology and Management 204: 345-357.

Martins, A.P.; Anghinoni, I.; Costa, S.E.V.G.A.; Carlos, F.S.; Nichel, G.H.; Silva, R.A.P.; Carvalho, P.C.F. 2014. Amelioration of soil acidity and soybean yield after surface lime reapplication to a long-term no-till integrated crop-livestock system under varying grazing intensities. Soil and Tillage Research 144: 141-149.

Matschonat, G.; Falkengren-Grerup, U. 2000. Recovery of soil $\mathrm{pH}$, cation-exchange capacity and the saturation of exchange sites from stemflow-induced soil acidification in three Swedish beech (Fagus sylvatica L.) forests. Scandinavian Journal of Forest Research 15: 39-48

Mina, B.L.; Saha, S.; Kumar, N.; Srivastva, A.K.; Gupta, H. S. 2008. Changes in soil nutrient content and enzymatic activity under conventional and zero-tillage practices in an Indian sandy clay loam soil. Nutrient Cycling in Agroecosystems 82: 273-281.

Miyazawa, M.; Pavan, M.A.; Franchini, J.C. 2002. Evaluation of plant residues on the mobility of surface applied lime. Brazilian Archives of Biology and Technology 45: 251-256.

Ning, P.; Li, S.; Yu, P.; Zhang, Y.; Li, C. 2013. Post-silking accumulation and partitioning of dry matter, nitrogen, phosphorus and potassium in maize varieties differing in leaf longevity. Field Crops Research 144: 19-27.

Oliveira, E.L.; Pavan, M.A. 1996. Control of soil acidity in notillage system for soybean production. Soil and Tillage Research 38: 47-57.

Panettieri, M.; Knicker, H.; Berns, A.E.; Murillo, J.M.; Madejón, E. 2013. Moldboard plowing effects on soil aggregation and soil organic matter quality assessed by ${ }^{13} \mathrm{C}$ CPMAS NMR and biochemical analyses. Agriculture, Ecosystems and Environment 177: 48-57. 
Peng, Y.F.; Yu, P.; Zhang, Y.; Sun, G.; Ning, P.; Li, X.X.; Li, C.J. 2012. Temporal and spatial dynamics in root length density of field-grown maize and NPK in the soil profile. Field Crops Research 131: 9-16.

Roelofs, J.G.M.; Bobbink, R.; Brouwer, E.; De Graaf, M.C.C. 1996. Restoration ecology of aquatic and terrestrial vegetation on non-calcareous sandy soils in The Netherlands. Acta Botanica Neerlandica 45: 517-541.

Roth, C.H.; Pavan, M.A. 1991. Effects of lime and gypsum on clay dispersion and infiltration in samples of a Brazilian Oxisol. Geoderma 48: 351-361.

Sá, J.C.M.; Lal, R.; Dick, W.A.; Piccolo, M.C.; Feigl, B.E. 2009. Soil organic carbon and fertility interactions affected by a tillage chronosequence in a Brazilian Oxisol. Soil and Tillage Research 104: 56-64.

Sánchez, P.A.; Salinas, J.G. 1981. Low input technology for managing Oxisols and Ultisols in tropical America. Advances in Agronomy 34: 280-406.

Selles, F.; Kochhann, R.A.; Denardin, J.E.; Zentner, R.P.; Faganello, A. 1997. Distribution of phosphorus fractions in Brazilian Oxisol under different tillage systems. Soil and Tillage Research 44: 23-34.

Shi, Y.; Ziadi, N.; Messiga, Aimé J.; Lalande, R.; Hu, Z. 2013. Changes in soil phosphorus fractions for a long-term cornsoybean rotation with tillage and phosphorus fertilization. Soil Science Society of America Journal 77: 1402-1412.
Sparks, D.L.; Page, A.L.; Helmke, P.A.; Loeppert, R.H.; Soltanpour, P.N.; Tabatabai, M.A.; Johnston, C.T.; Sumner, M.E. 1996. Methods of soil analysis: chemical methods. Soil Science Society of America, Madison, WI, USA.

Tan, Z.X.; Lal, R. 2005. Carbon sequestration potential estimates with changes in land use and tillage practice in Ohio, USA. Agriculture Ecosystems and Environment 111: 140-152.

Vieira, F.C.B.; Bayer, C.; Zanatta, J.A.; Dieckow, J.; Mielniczuk, J.; He, Z.L. 2007. Carbon management index based on physical fractionation of soil organic matter in an Acrisol under longterm no-till cropping systems. Soil and Tillage Research 96: 195-204.

Volz, M.G.; Jacobson, L. 1977. Nature and magnitude of calcium uptake by excised roots of vetch and barley. Plant and Soil 46: 79-91.

Wyngaard, N.; Echeverría, H.E.; Rozas, H.R.S.; Divito, A.G. 2012. Fertilization and tillage effects on soil properties and maize yield in a Southern Pampas Argiudoll. Soil and Tillage Research 119: 22-30. 